\title{
Apoptotic effect of Vibrio vulnificus cytolysin on A549 human lung adenocarcinoma cells
}

\author{
JIACHUN SUN, JING ZHENG, GUIMING WANG, YAN LI and HONG SHEN \\ Department of Pathology, Southern Medical University, Guangzhou, Guangdong 510515, P.R. China
}

Received August 24, 2011; Accepted November 14, 2011

DOI: $10.3892 / \mathrm{mmr} .2011 .690$

\begin{abstract}
Vibrio vulnificus cytolysin (VVC) has a very strong cytotoxic effect on various types of mammalian cells. However, the inhibitory effect of VVC on the proliferation of human lung cancer cells has scarcely been reported. This study aimed to analyze the effects of recombinant VVC (rVVC) on the A549 human lung adenocarcinoma cell line and to investigate the underlying molecular mechanisms governing these effects. This study showed that rVVC inhibited the proliferation of A549 cells in a concentration- and time-dependent manner (as measured by the MTT assay). rVVC failed to induce the release of intracellular lactate dehydrogenase (LDH) from the target cells suggesting that osmotic lysis may not contribute to its cytolysin-induced cytotoxicity. Treatment of A549 cells with an $\mathrm{IC}_{50}$ (concentration of drug that inhibits cell growth by $50 \%$ ) of rVVC resulted in morphological changes and blebbing typical of apoptosis. Annexin-V FITC analysis by FCM indicated that rVVC-induced apoptosis in A549 cells occurs in a dosedependent manner. A DNA fragmentation assay was utilized to investigate the apoptosis induced by rVVC. The pro-apoptotic activity of rVVC was attributed to its ability to modulate, in a concerted manner, the expression of $\mathrm{Bcl}-2$ and Bax proteins, which were down- and up-regulated, respectively. Caspase-9 and -3 were subsequently activated, however caspase- 8 was not. These results prove that $\mathrm{rVVC}$ effectively induces programmed cell death and suggests that rVVC-induced apoptosis in the A549 cell line is mediated by the regulation of Bcl-2 protein expression and the activation of caspase- 9 and -3 .
\end{abstract}

\section{Introduction}

Vibrio vulnificus is a gram-negative, halophilic bacterium that inhabits marine and estuarine areas. It may cause wound infection, gastroenteritis and primary septicemia in humans. The mortality rates reach as high as $55 \%$ in primary septicemia

Correspondence to: Professor Hong Shen, Department of Pathology, Southern Medical University, No. 1838 North Guangzhou Avenue, Guangzhou, Guangdong 510515, P.R. China

E-mail: shenhong20101681@163.com

Key words: Vibrio vulnificus cytolysin, A549, apoptosis, Bcl-2/ Bax, caspase-9/3
(1-3). Previous studies have demonstrated that various components and metabolites of Vibrio vulnificus such as its cytolysin, toxic cytokines, MMPs and so on, may serve as toxic factors and play an important role in pathogenesis. Among these various pathogenic factors, Vibrio vulnificus cytolysin (VVC) attracted our interest, since it perforates the cell membrane and exerts cytotoxic effects on mammalian cells.

VVC, a polypeptide with a molecular weight of 50851, is encoded by the vvhA gene. It is produced by most pathogenic strains, is water-soluble and demonstrates thermal instability. VVC is an extremely active exotoxin and is characteristic of the Vibrio vulnificus species. In addition to hemolytic activities (4-5), VVC destroys various other mammalian cells including mast (6,7), macrophages (8) and endothelial cells (9). Studies have shown that VVC perforates the target cell membrane by binding to cholesterol in the host cell membrane and plays an important role in the dissolution of cells $(10,11)$. Rho et al found that a low concentration of VVC induced apoptosis in CAPE (12). Kwon et al studied the effects of VVC in EVC304 cells. The results from this study suggested that cell apoptosis induced by VVC was triggered by superoxide anion generation, cytochrome c release, caspase- 3 activation, ADP ribose polymerase degradation and DNA cleavage (13). Recently Zhao et al also found that VVC induced apoptosis in HUVEC, SGC-7901 and SMMC-7721 cells through the activation of the caspase-9 and -3 pathway (14). Literature studies show that VVC produces potent cytotoxicity in various mammalian cells. However, few studies have been conducted to investigate the cytotoxic effects of VVC on lung cancer cells to date.

In this study, we analyzed the cytotoxic effects of recombinant (r)VVC on A549 cells (human lung adenocarcinoma cells) in vitro and investigated the possible mechanisms involved. Our results suggest that rVVC may down-regulate Bcl-2 while up-regulating Bax, thereby triggering apoptotic signals leading to the death of A549 cells.

\section{Materials and methods}

Culture of the bacterial strain and cell lines. Vibrio vulnificus ATCC27562 was purchased from the China General Microbiological Culture Collection Center, and was cultured in $2.5 \% \mathrm{NaCl}$ heart infusion (HI) medium (Difco, USA) at $37^{\circ} \mathrm{C}$. A549 cells were purchased from the Cell Bank of the Institute of Cellular Biology in Shanghai (Chinese Academy of Science) and were cultured in RPMI-1640 medium (Gibco, 
USA) supplemented with 10\% FBS (Gibco) in humidified air with $5 \% \mathrm{CO}_{2}$ at $37^{\circ} \mathrm{C}$.

Purification of $r V V C$. Genomic DNA of Vibrio vulnificus strain ATCC27562 was extracted by the phenol-chloroform method. The entire vvhA gene was amplified by PCR with specific primers: 5'-C-GGATCCCAAGAATATGTGCCGATTGT-3' BamHI (forward), and 5'-CCG-CTCGAG-CTAGAGTTTGACTTGTTGT-3' XhoI (reverse). The PCR was initiated by incubation at $94^{\circ} \mathrm{C}$ for $5 \mathrm{~min}$, followed by 35 cycles at $94^{\circ} \mathrm{C}$ for $30 \mathrm{sec} /$ cycle, $52^{\circ} \mathrm{C}$ for $30 \mathrm{sec}$ and $72^{\circ} \mathrm{C}$ for $120 \mathrm{sec}$ to amplify the vvhA gene. Finally, the PCR products were incubated at $72^{\circ} \mathrm{C}$ for $10 \mathrm{~min}$. The PCR products were cloned into the pGEM-T vector (Takara, Japan) for sequencing. Having been confirmed by sequence analysis (Takara), the cloned vvhA gene was subcloned into the pET32a vector (Novagen, USA) by the BamHI-XhoI sites to form pET32a-vvhA, and then the recombinant plasmid was transformed into competent $E$. coli BL21 (DE3) (Novagen, USA). rVVC was expressed by E. coli BL21 (DE3) pET-32a-vvhA under the induction of $1 \mathrm{mmol} / \mathrm{l}$ IPTG (Merck, Germany) at $30^{\circ} \mathrm{C}$. After ultrasonication and centrifugation, the expression of rVVC was analyzed by SDS-PAGE Plus Bio-Rad Gel Image Analyzer (Bio-Rad, USA). Afterwards the cytolysin with His-tag in the cell lysate was purified by binding with Ni-IMAC resin (GenScript, USA).

Hemolysis assay. The hemolytic activity of rVVC against mouse erythrocytes was investigated according to the procedure described by Bernheimer and Schwartz (15). Briefly, the purified rVVC was diluted with $0.1 \%$ BSA-PBS (pH 7.4) to different concentrations, and incubated with the same volume of a $0.5 \%$ mouse erythrocyte suspension for different periods of time at $37^{\circ} \mathrm{C}$. After centrifugation at $2000 \mathrm{rpm}$ for $5 \mathrm{~min}$, the absorbance values of each supernatant were assayed at $545 \mathrm{~nm}$.

Cell viability assay. A549 cells in the logarithmic growth phase were plated at a density of $3 \times 10^{4}$ cells $/ \mathrm{ml}$ in 96 -well plates. Twenty-four hours later, 5, 10, 15, 20, 25 and $30 \mu \mathrm{g} /$ $\mathrm{ml}$ of rVVC was added, respectively. After 24,48 and $72 \mathrm{~h}$ of incubation, the culture medium was discarded and $20 \mu \mathrm{l}$ MTT solution $(5 \mathrm{mg} / \mathrm{ml} \mathrm{PBS})$ was added to each well. Then the plates were incubated for another $4 \mathrm{~h}$ at $37^{\circ} \mathrm{C}$, the supernatant was removed and $200 \mu \mathrm{l}$ of DMSO was added to each well. Finally, the optical density (OD) was assayed at a 570-nm wavelength using a Bio-Rad Model 680 microplate reader (Bio-Rad). Cell inhibition ratio (I\%) and $\mathrm{IC}_{50}$ were then calculated (16).

Detection of cellular LDH. A549 cells were seeded in 6-well plates at a density of $3 \times 10^{5}$ cells $/ \mathrm{ml}$ and incubated for $24 \mathrm{~h}$. The cells were subsequently incubated with $10 \mu \mathrm{g} / \mathrm{ml} \mathrm{rVVC} \mathrm{at} 37^{\circ} \mathrm{C}$ for $0.5,2,4$ and $8 \mathrm{~h}$, respectively. Normal controls were untreated with rVVC. The cells were harvested and after transient centrifugation, the supernatants were collected. The OD500 value was measured to examine the activity of LDH in the supernatants by dinitro-phenyl-hydrazine (DPNH) colorimetry.

Cell morphological assessment. A549 cells were seeded in 6 -well plates and treated with $10 \mu \mathrm{g} / \mathrm{ml} \mathrm{rVVC}$ for $24 \mathrm{~h}$. At the end of the incubation, cell morphology was observed and photographed using an inverted light microscope. Afterwards, the cells were collected and fixed with $4 \%$ formaldehyde in PBS for $15 \mathrm{~min}$ and stained with Hoechst $333258(10 \mathrm{mg} / \mathrm{ml})$ at room temperature for $10 \mathrm{~min}$. Finally, after the cells were washed with PBS, the morphology of the cells was monitored under a fluorescence microscope and photographed at $\times 300$ magnification.

Cell ultrastructure observation. A549 cells were treated with $10 \mu \mathrm{g} / \mathrm{ml} \mathrm{rVVC}$ at $37^{\circ} \mathrm{C}$ for $24 \mathrm{~h}$, and then collected and washed with PBS, followed by fixation with $2.5 \%$ glutaral solution at $4^{\circ} \mathrm{C}$ and embedding in paraffin. Sections of the cell samples were observed and photographed by using transmission electron microscopy (Philips, Holland).

Annexin V-FITC/PI analysis. A549 cells were seeded in 6-well plates at a density of $3 \times 10^{5}$ cells $/ \mathrm{ml}$ and incubated for $24 \mathrm{~h}$. Then they were incubated with concentrations of 5, 10 and $20 \mu \mathrm{g} / \mathrm{ml}$ of rVVC for $24 \mathrm{~h}$. Afterwards, they were harvested and treated according to the manufacturer's instructions for both the samples described above. Data acquisition and analysis were performed on a Becton Dickinson FACSCalibur flow cytometer using the Cell Quest software (Franklin Lakes, NJ, USA).

Measurement of DNA fragmentation. A549 cells were grown in 6-well plates at a density of $3 \times 10^{5}$ cells $/ \mathrm{ml}$ and were incubated without $\mathrm{rVVC}$ and with 5,10 and $20 \mu \mathrm{g} / \mathrm{ml} \mathrm{rVVC}$ for $24 \mathrm{~h}$. Then cells were harvested, washed, and lysed in buffer $(10 \mathrm{mM}$ Tris- $\mathrm{HCl} \mathrm{pH} \mathrm{7.5,} 400 \mathrm{mM} \mathrm{NaCl}, 100 \mathrm{mM}$ EDTA, $0.6 \% \mathrm{SDS}$ ) at $55^{\circ} \mathrm{C}$ for $3 \mathrm{~h}$, followed by the addition of RNase $(4 \mathrm{mg} / \mathrm{ml})$, and further incubation at $55^{\circ} \mathrm{C}$ for $18 \mathrm{~h}$. The lysates were centrifuged at $10,000 \mathrm{x}$ g for $20 \mathrm{~min}$. The genomic DNA in the supernatant was electrophoresed on a $1.5 \%$ agarose gel at $100 \mathrm{~V}$ for $2 \mathrm{~h}$ and analyzed. The fragmented inter-nucleosomal DNA was visualized using a UV trans-illuminator.

Western blot analysis. A549 cells were treated with rVVC at different concentrations $(0,5,10$ and $20 \mu \mathrm{g} / \mathrm{ml})$ for $24 \mathrm{~h}$. Then the cells were re-suspended in cell lysis buffer (1\% Triton X-100, $0.015 \mathrm{M} \mathrm{NaCl}, 10 \mathrm{mM}$ Tris-HCl, $1 \mathrm{mM}$ EDTA, $1 \mathrm{mM}$ PMSF, $10 \mu \mathrm{g} / \mathrm{ml}$ of each leupeptin and pepstatin A) and then incubated on ice for $30 \mathrm{~min}$. The cell lysates were centrifuged at $12000 \mathrm{x} \mathrm{g}$ for $15 \mathrm{~min}$ at $4^{\circ} \mathrm{C}$. One part of the supernatant was mixed with four parts of SDS sample buffer, boiled for $5 \mathrm{~min}$, then separated through a $12 \%$ SDS-PAGE gel. After electrophoresis, the proteins were transferred to nylon membranes following the manufacturer's instructions (Bio-Rad). The membranes were blocked in 5\% dry skimmed milk $(1 \mathrm{~h})$, rinsed, and incubated with primary and secondary antibodies (diluted 1:2000) in TBS at room temperature for $2 \mathrm{~h}$. Finally each protein was detected using an enhanced chemiluminescence system (GE Healthcare, USA).

Caspase activity detection. After incubation with $10 \mu \mathrm{g} / \mathrm{ml}$ rVVC for $24 \mathrm{~h}, \mathrm{~A} 549$ cells $\left(5 \times 10^{6}\right)$ were collected and washed with PBS. The collected cells were treated according to the protocols described in the Caspase- $3,-8$ and -9 fluorometric assay kits (Biovision, USA). The activities of caspase- $3,-8$ and -9 were measured using a spectrofluorometer (Hitachi, 


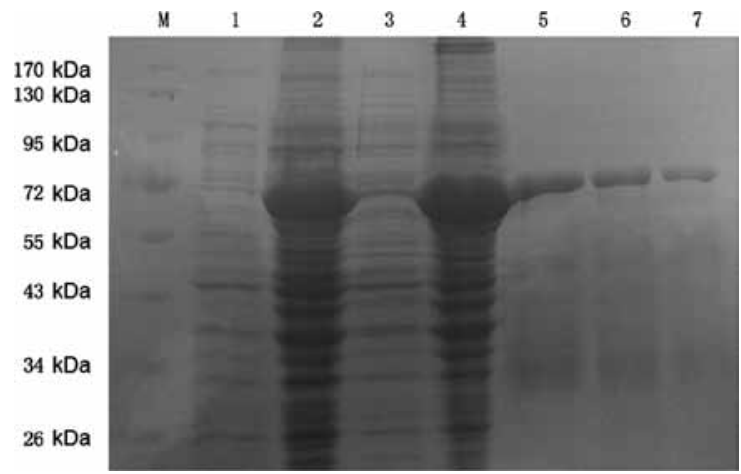

Figure 1. Expression and purification of rVVC. rVVC was expressed by E. coli BL21(DE3)pET-32a-vvhA (2) under the induction of $1 \mathrm{mmol} / \mathrm{l}$ IPTG at $37^{\circ} \mathrm{C}$ and (1) control bacteria were left un-induced. (3) Expressed rVVC was present in the supernatant and (4) precipitant of the lytic bacteria, and (5-7) the purified rVVC presented a single protein fragment.

Japan) with an excitation and an emission wavelength of 400 and $505 \mathrm{~nm}$, respectively.

Statistical analysis. Data are expressed as the means \pm SD. Statistical analysis was performed with ANOVA using SPSS 13.0 software. Differences were considered significant when $\mathrm{P}$-value was $<0.05$.

\section{Results}

Purification of $r V V C . r V V C(\sim 70 \mathrm{kDa})$ was expressed by E.coli BL21(DE3)pET-32a-vvhA in LB medium under the induction of $1 \mathrm{mmol} / \mathrm{l}$ IPTG, and its yield amounted to approximately $58 \%$ of the total bacterial protein (Fig. 1). Since the recombinant protein which we obtained was expressed in insoluble (inclusion body) forms, we used the method of dialysis to refold the diluted purified protein using a refolding medium with $15 \%$ glycerol, thus ensuring stability of the protein.

Hemolytic activities of rVVC towards mouse erythrocytes. The purified rVVC was confirmed to possess hemolytic activity by a hemolysis test. After incubation with mouse erythrocytes for different periods of time and at different concentrations, VVC showed hemolytic activity that was both incubation time- and dose-dependent (Fig. 2A).

Cell viability assay. An MTT assay showed that $\mathrm{rVVC}$ significantly inhibited the proliferation of A549 cells (Fig. 2B). Cells were incubated in the absence and presence of different $\mathrm{rVVC}$ concentrations for 24,48 and $72 \mathrm{~h}$. rVVC had a significant growth-inhibiting effect on the A549 cell line. The inhibitory effects of rVVC on A549 cells was dose- and time-dependent. The $\mathrm{IC}_{50}$ value $(24 \mathrm{~h})$ for $\mathrm{rVVC}$ treatments was $8.59 \mu \mathrm{g} / \mathrm{ml}$.

Detection of cellular LDH. As shown in Fig. 2C, after treatment with $10 \mu \mathrm{g} / \mathrm{ml} \mathrm{rVVC}$ at $37^{\circ} \mathrm{C}$ for different periods of time, there was no significant change in LDH activity in all supernatants of the rVVC-treated cells $(\mathrm{P}>0.05)$.

Cell morphological assessment. Fluorescence microscopic analysis showed marked morphological features of apoptosis
A

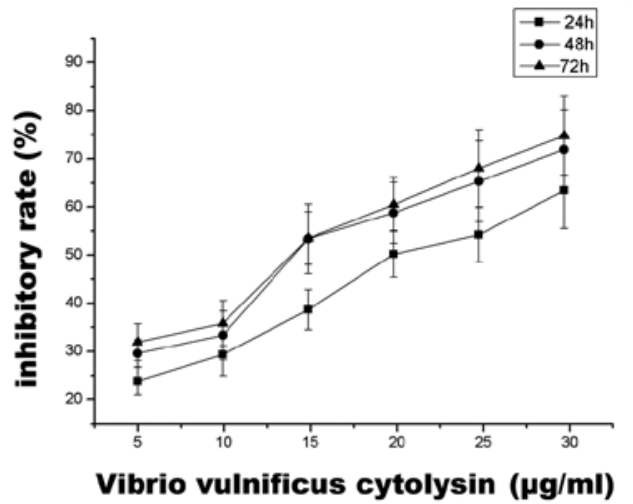

B

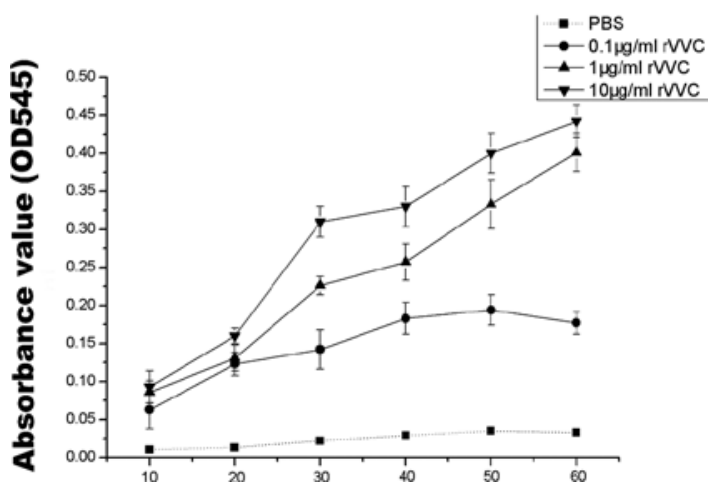

C

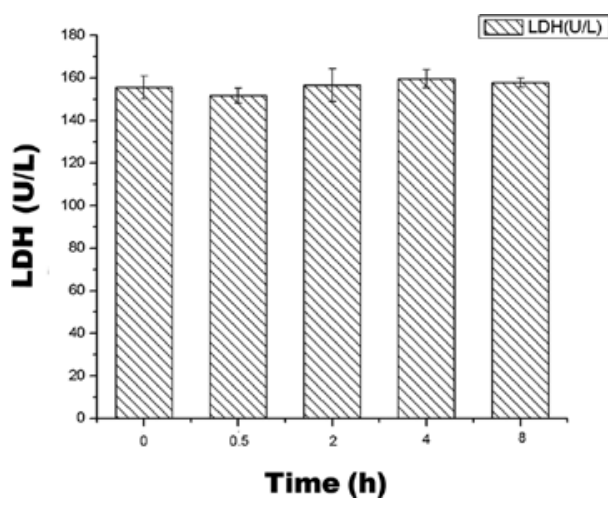

Figure 2. (A) Hemolytic activity of the rVVC towards mouse erythrocytes $($ mean $\pm \mathrm{SD}, \mathrm{n}=3)$. Mouse erythrocytes were incubated with $0.1,1$ and $10 \mu \mathrm{g} / \mathrm{ml}$ rVVC for various time intervals, and the OD545 in supernatants was measured to reflect the hemolytic activity of rVVC. (B) Growth-inhibitory effects of rVVC on A549 cells. Cells were treated with various concentrations of rVVC as indicated. (C) Effects of rVVC on LDH activity in A549 cells. A549 cells were treated with $10 \mu \mathrm{g} / \mathrm{ml} \mathrm{rVVC}$ for $0.5,2,4$ and $8 \mathrm{~h}$ and LDH activity was detected by dinitro-phenyl-hydrazine (DPNH) colorimetry. Data are shown as the mean $\pm S D(n=3) ; P>0.05$ vs. the untreated controls.

in A549 cells such as brighter nuclei and nuclear condensation when treated with $\mathrm{rVVC}(10 \mu \mathrm{g} / \mathrm{ml})$ for a period of $24 \mathrm{~h}$ (Fig. 3B). A549 cells were incubated with $10 \mu \mathrm{g} / \mathrm{ml} \mathrm{rVVC} \mathrm{for}$ $24 \mathrm{~h}$ and typical apoptotic characteristics including crescentshaped nuclei and chromatin condensation were found under transmission electron microscopy (Fig. 3C).

Apoptosis assessment by Annexin-V and PI double-staining assay. The percentage of apoptotic cells (Annexin- $\mathrm{V}^{+} / \mathrm{PI}^{+}$and Annexin- $\left.\mathrm{V}^{+} / \mathrm{PI}\right)$ in the control group was $7.01 \%$. After treatment with 5,10 and $20 \mu \mathrm{g} / \mathrm{ml} \mathrm{rVVC}$ for $24 \mathrm{~h}$, the percentages 
A
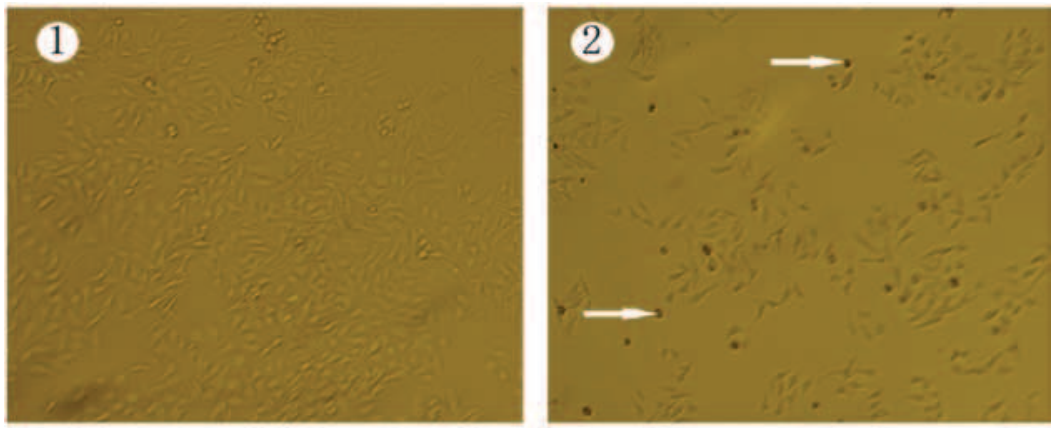

B
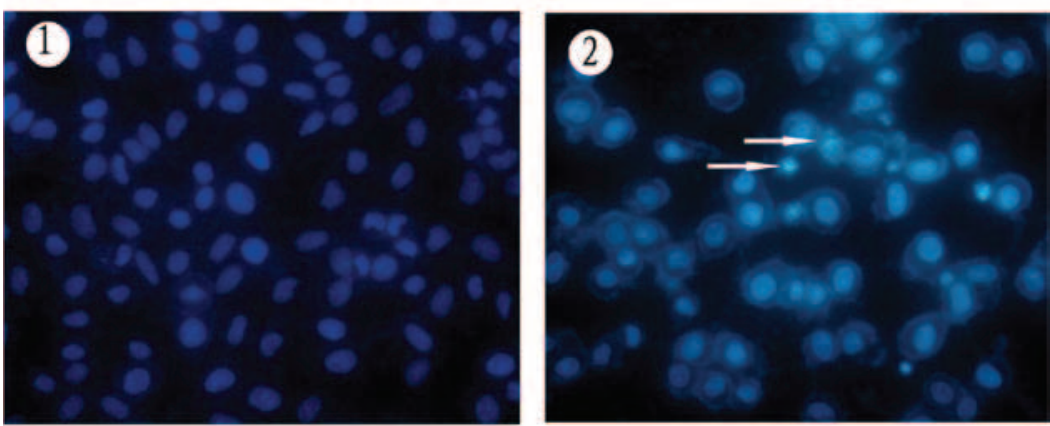

$\mathbf{C}$
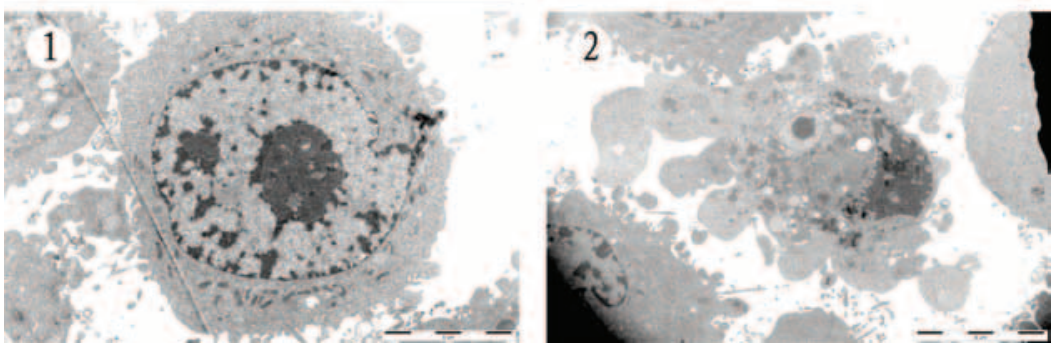

Figure 3. Morphologic changes of A549 cells treated with $10 \mu \mathrm{g} / \mathrm{ml} \mathrm{rVVC} \mathrm{for} 24 \mathrm{~h}$ compared with the untreated cells (control). Cells were grown in 6-well plates and treated in the presence or absence of rVVC for $24 \mathrm{~h}$. Exposure of A549 cells to $10 \mu \mathrm{g} / \mathrm{ml} \mathrm{rVVC} \mathrm{provoked} \mathrm{significant} \mathrm{morphological} \mathrm{changes:} \mathrm{(A1-2)}$ Cells had shrunk and retracted from their neighbors, floating cells appeared in the culture medium and most of the A549 cells lost their flat, polygonal shape. (B1-2) Nuclear morphology was also observed by Hoechst 333258 staining. Arrows identify apoptotic cells with bright, nuclear condensation. Cells were incubated with $10 \mu \mathrm{g} / \mathrm{ml} \mathrm{rVVC} \mathrm{for} 24 \mathrm{~h}$, and photographed under transmission electron microscopy at x6200 magnification. (C1-2) Typical apoptotic characteristics were observed in A549, compared with the untreated A549.

A

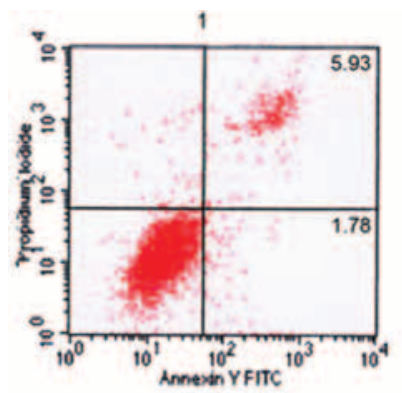

3

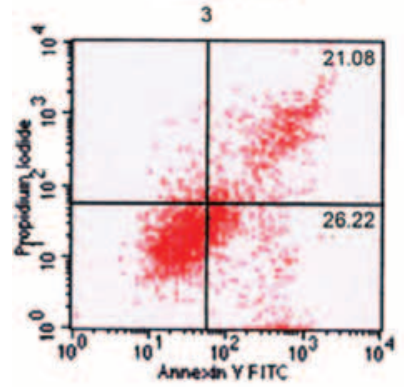

2
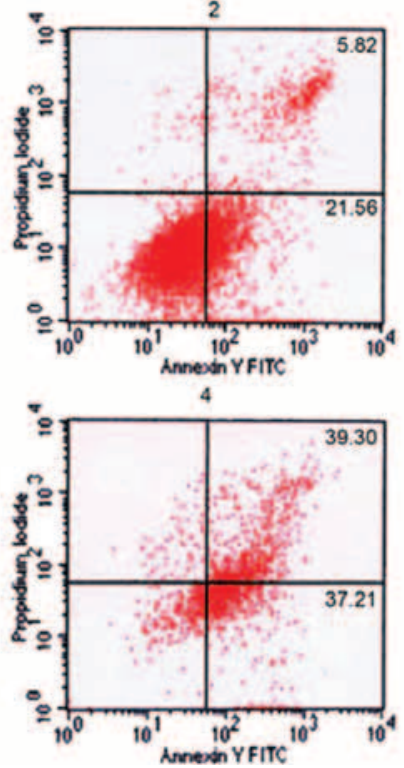

B
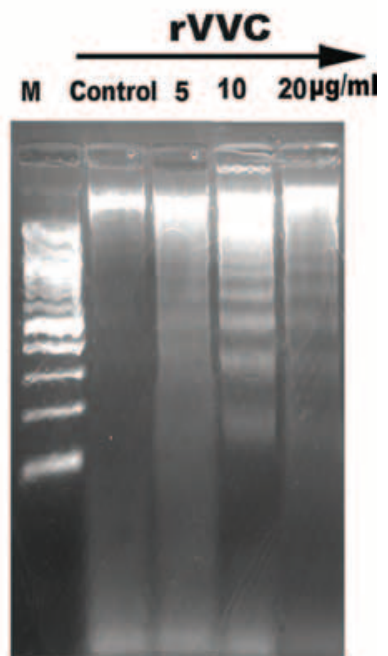

Figure 4. (A) Dosage-dependent apoptosis in rVVC-treated cells detected by flow cytometry. Cells were incubated with various concentrations of rVVC for $24 \mathrm{~h}$ and apoptosis was detected by flow cytometric analysis after staining with Annexin V-FITC and propidium iodide (PI). Numbers $1-4$ represent the normal control, and the cells treated with 5, 10 and $20 \mu \mathrm{g} / \mathrm{ml} \mathrm{rVVC} \mathrm{for} 24 \mathrm{~h}$, respectively. (B) Analysis of DNA integrity in the rVVC-treated A549 cells by agarose electrophoresis. A549 cells were treated with different concentrations $(5,10$ and $20 \mu \mathrm{g} / \mathrm{ml})$ of rVVC for $24 \mathrm{~h}, \mathrm{DNA}$ from the cells was extracted and electrophoresed on a $1.5 \%$ agarose gel and visualized using a UV trans-illuminator. 


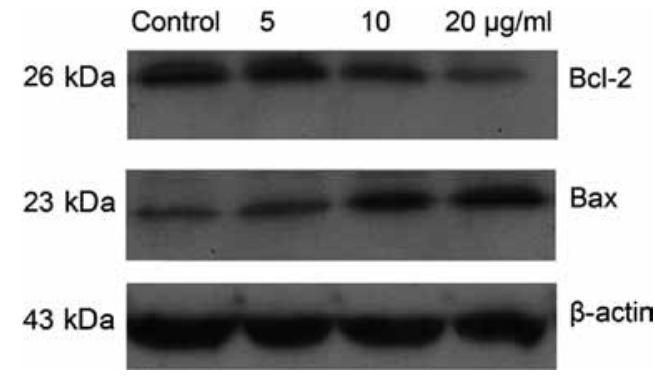

Figure 5. Bax and Bcl-2 expression. Whole cell lysate was obtained and used for Western blot analysis with Bax and Bcl-2 antibodies. $\beta$-Actin was used as an equal loading control.

of apoptotic cells were $27.38,47.30$ and $76.51 \%$, respectively (Fig. 4A).

DNA fragment assay. Chromosomal DNA from untreated and A549 cells treated with $\mathrm{rVVC}(5,10$ and $20 \mu \mathrm{g} / \mathrm{ml})$ for $24 \mathrm{~h}$, was isolated, extracted and resolved using agarose gel electrophoresis. Results of the DNA integrity analysis showed that $\operatorname{rVVC}(5,10$ and $20 \mu \mathrm{g} / \mathrm{ml})$ caused the digestion of genomic DNA into ladders as was expected (Fig. 4B).

Expression of $\mathrm{Bcl}-2$ and Bax proteins. Western blot analysis indicated that the expression of $\mathrm{Bcl}-2$ protein decreased slightly, while the expression of Bax protein dramatically increased when compared to the control. This resulted in a large change in the Bcl-2/Bax ratio (Fig. 5).

Activation of caspase-9 and caspase-3 during rVVC-induced apoptosis. As shown in Fig. 6, there was an increase in caspase-3 activity in the rVVC-treated A549 cells (Fig. 6A). Caspase-9 activity also exhibited an increase (Fig. 6B). However, no alteration in caspase- 8 activity was found in all of the cells tested (Fig. 6C). These data indicate that the apoptosis induced by rVVC was mediated by caspase- 9 activation rather than caspase-8 activation.

\section{Discussion}

Although VVC is an exotoxin that is characteristic of Vibrio vulnificus, the yield of secretion of natural cytolysin from Vibrio vulnificus culture is relatively low (3). It is very difficult to attain sufficiently high purity of VVC by routine biochemical methods. Therefore, we constructed the pET32a $(+)$-vvhA expression vector and also succeeded in optimizing the conditions required for the expression, purification and renaturation of the toxin. This has laid the foundation for further studies on the biological activity of rVVC.

It has been demonstrated that other pore-forming toxins such as staphylococcal-toxin (17), streptolysin-O (18) and Vibrio cholerae E1 Tor cytolysin (19) possess cytotoxicity toward nucleated cells. Their mechanism of the cytotoxic activity mainly involves 'punching' holes in the cell membrane and causing the dissolution of target cells. It was reported that a member of the pore-forming toxin family, VVC, binds to the surface of target cell membranes, forms oligomers and creates holes in the cell membrane. The pore-mediated osmotic
A

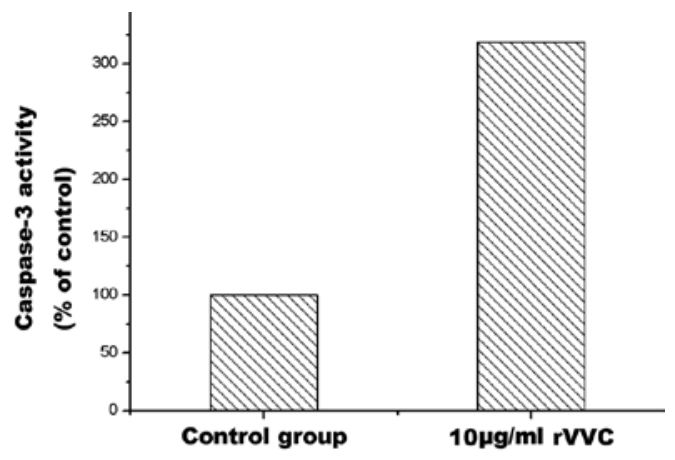

B

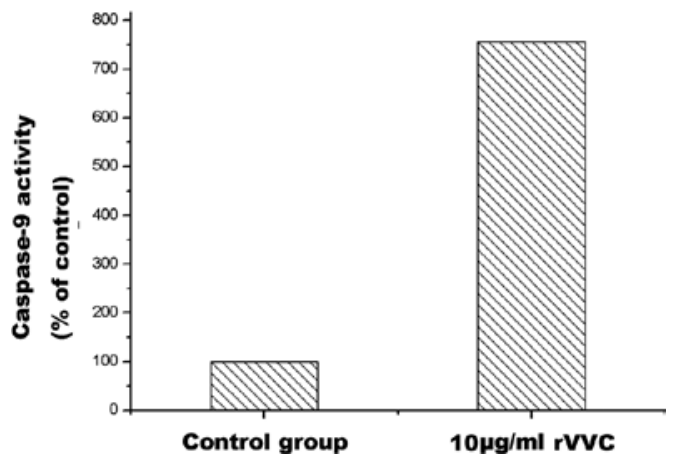

C

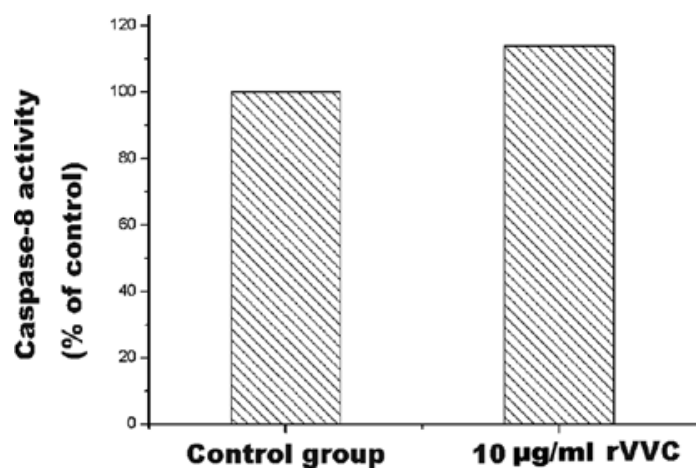

Figure 6. Changes in caspase-3, -8 and -9 activities in the rVVC-treated cells. Cells were incubated with $10 \mu \mathrm{g} / \mathrm{ml} \mathrm{rVVC}$ for $24 \mathrm{~h}$. Cytosolic extracts were assayed for caspase-3, -8 and -9 activities based on the detection of fluorescence of AFC from cleavage of their specific substrates. Comparison of the fluorescence from apoptotic samples with un-induced controls allows determination of the increase in caspase activity.

lysis was always accompanied by the quick leaking out of cytoplasmic LDH. Thus, LDH activity in cell culture media may indirectly reflect the condition of cell injury. However, we discovered that after treatment with $\mathrm{rVVC}(10 \mu \mathrm{g} / \mathrm{ml})$ for different periods of time, the LDH activity in the culture media of A549 cells showed no obvious change when compared with the control groups $(\mathrm{P}>0.05)$. Therefore, we speculated that the inhibition of proliferation in A549 cells by rVVC may not be through the induction of pore-formation and dissolution.

In order to explore the mechanism of inhibition of the proliferation of A549 cells by rVVC, we studied the effect of rVVC on apoptosis in A549 cells. Apoptosis is a mode of programmed cell death that is an important physiological process responsible for maintaining homeostasis (20). A dysregulation of apoptosis plays a central role in aberrant cell survival and tumorigenesis (21). Apoptosis is characterized by chromatin condensation, DNA fragmentation, membrane blebbing, and/ 
or apoptotic bodies (22). In our study, both Annexin-V FITC analysis by FCM and Hochest 333258 staining assay in vitro displayed higher percentages of apoptotic cells in A549 cells treated with rVVC. When the A549 cells were treated with $10 \mu \mathrm{g} / \mathrm{ml} \mathrm{rVVC}$ for $24 \mathrm{~h}$, marked morphological changes were clearly observed by using a transmission electron microscope. To further confirm the rVVC-induced apoptotic responses in A549 cells, chromosomal DNA from rVVC-untreated and $\mathrm{rVVC}(5,10$ and $20 \mu \mathrm{g} / \mathrm{ml})$-treated cells was analyzed by DNA fragmentation analysis. rVVC treatment resulted in inter-nucleosomal DNA cleavage in A549 cells as indicated by DNA laddering, while the inter-nucleosomal DNA from untreated cancer cells remained intact. The above results indicate that rVVC induced A549 cell apoptosis and indirectly inhibited A549 cell growth.

Apoptosis is tightly regulated by multiple pathways and proteins. Among the numerous proteins and genes involved, the members of the Bcl-2 family play a critical role in inhibiting or promoting apoptosis. The Bcl-2 family is composed of both anti-apoptotic molecules (Bcl-2,Bcl-W,Bcl-XL,A1) and pro-apoptotic molecules (Bax, Bcl-Xs, Bad, Bak, Bid, Bim, Bik) $(22,23)$. Although an important anti-apoptosis protein, Bcl-2, may take part in the formation of mitochondrial PT (permeability transition) holes, however, only at a high $\mathrm{pH}$. On the other hand Bax may form holes at a large range of $\mathrm{pHs}$, and is considered pro-apoptotic. Bax permits some ions and small molecules such as cytochrome $\mathrm{C}$ to penetrate the mitochondrial membrane and enter the cytoplasm, causing cell apoptosis. However the function of $\mathrm{Bcl}-2$ is the opposite. It negates the hole-forming activity by Bax and prevents small molecules from penetrating freely, thus protecting cells from apoptosis (23-27). Thus, the ratio between the two subsets helps determine, partly, the susceptibility of cells to a death signal. Our study detected a slight decrease in Bcl-2 and an increase in Bax protein in rVVC-treated A549 cells, resulting in a decrease in the $\mathrm{Bc1}-2 / \mathrm{Bax}$ ratio. Therefore, we propose that $\mathrm{Bcl}-2$ protein primarily participates in $\mathrm{rVVC}$-induced apoptosis in A549 cells.

Caspases, intracellular cysteine proteases, may cause apoptosis by two major pathways, namely FADD-caspase-8/3 and cytochrome $\mathrm{C}$ (CytC)-caspase-9/3. The FADD-caspase$8 / 3$ route is triggered by Fas/FasL, and the CytC-caspase- $9 / 3$ route is initiated by mitochondrial injury. Finally, caspase-3, an endogenous endonuclease, is activated, which causes irreversible cell apoptosis (28-30). We measured the changes in caspase-3, -8 and -9 activity by colorimetric assay. Our results showed that caspase-3 and -9 activities in rVVC-treated A549 cells were markedly elevated, whereas caspase- 8 activity was not affected by rVVC. These data strongly suggest that the apoptosis caused by rVVC was mitochondrion-dependent, and not related to the Fas/FasL and FADD-caspase- 8 route. This implies the possibility that the mitochondrion-associated CytC-caspase- $9 / 3$ route may be responsible for $\mathrm{rVVC}$-induced apoptosis.

In summary, our study conclusively demonstrated for the first time that $\mathrm{rVVC}$ inhibits proliferation and induces apoptosis in the A549 cell line. The mechanism of apoptosis involves down-regulation of Bcl-2 and up-regulation of Bax protein expression. Furthermore, the apoptosis is mediated by the mitochondrion-associated caspase $9 / 3$ pathway. This means that the mechanism of 'punching' holes in the cell membrane does not accurately describe the pathogenic effects of this toxin. However, the elucidation of precise mechanisms underlying these effects needs further study.

\section{References}

1. Mead PS, Slutsker L, Dietz V, McCaig LF, Bresee JS and Shapiro C: Food-related illness and death in the United States. Emerg Infect Dis 5: 607-625, 1999.

2. Jones MK and Oliver JD: Vibrio vulnificus: disease and pathogenesis. Infect Immun 77: 1723-1733, 2009.

3. Feldhusen F: The role of seafood in bacterial foodbourne diseases. Microbes Infect 2: 1651-1660, 2000.

4. Kim HR, Rho HW, Jeong MH, Park JW, Kim JS, Park BH, Kim UH and Park SD: Hemolytic mechanism of cytolysin produced from $V$. vulnificus. Life Sci 53: 571-578, 1993.

5. Park JW, Jahng TA, Rho HW, Park BH, Kim NH and Kim HR: Inhibitory mechanism of $\mathrm{Ca}^{2+}$ on the hemolysis caused by Vibrio vulnificus cytolysin. Biochim Biophys Acta 1194: 166-170, 1994.

6. Yamanaka H, Sugiyama K, Furuta H, Miyoshi S and Shinoda S: Cytolytic action of Vibrio vulnificus haemolysin on mast cells from rat peritoneal cavity. J Med Microbiol 32: 39-43, 1990.

7. Kim JS, Chae MR, Chang K, Park KH, Rho HW, Park BH, Park JW and Kim HR: Cytotoxicity of Vibrio vulnificus cytolysin on rat peritoneal mast cells. Microbiol Immunol 42: 837-843, 1998.

8. Kang MK, Jhee EC, Koo BS, Yang JY, Park BH, Kim JS, Rho HW, Kim HR and Park JW: Induction of nitric oxide synthase expression by Vibrio vulnificus cytolysin. Biochem Biophys Res Commun: 1090-1095, 2002.

9. Park KH, Lee YR, Hur H, Yu HN, Rah SY, Kim UH, Yu KY, Jin CM, Han MK and Kim JS: Role of calcium/calmodulin signaling pathway in Vibrio vulnificus cytolysin-induced hyperpermeability. Microb Pathog 47: 47-51, 2009.

10. Kim BS and Kim JS: Vibrio vulnificus cytolysin induces hyperadhesiveness of pulmonary endothelial cells for neutrophils through endothelial P-selectin: a mechanism for pulmonary damage by Vibrio vulnificus cytolysin. Exp Mol Med 34: 308-312, 2002.

11. Park KH, Yang HB, Kim HG, Lee YR, Hur H, Kim JS, Koo BS, Han MK, Kim JH, Jeong YJ and Kim JS: Low density lipoprotein inactivates Vibrio vulnificus cytolysin through the oligomerization of toxin monomer. Med Microbiol Immunol 194: 137-141, 2005.

12. Rho HW, Choi MJ, Lee JN, Park JW, Kim JS, Park BH, Sohn HS and Kim HR: Cytotoxic mechanism of Vibrio vulnificus cytolysin in CPAE cells. Life Sci 70: 1923-1934, 2002.

13. Kwon KB, Yang JY, Ryu DG, Rho HW, Kim JS, Park JW, Kim HR and Park BH: Vibrio vulnificus cytolysin induces superoxide anion-initiated apoptotic signaling pathway in human ECV304 cells. J Biol Chem 276: 47518-47523, 2001

14. Zhao JF, Sun AH, Ruan P, Zhao XH, Lu MQ and Yan J: Vibrio vulnificus cytolysin induces apoptosis in HUVEC, SGC-7901 and SMMC-7721 cells via caspase-9/3-dependent pathway. Microb Pathog 46: 194-200, 2009.

15. Bernheimer AW and Schwartz LL: Isolation and composition of staphylococcal alpha toxin. J Gen Microbiol 30: 455-468, 1963.

16. Bromberg N, Justo GZ, Haun M, Durán N and Ferreira CV: Violacein cytotoxicity on human blood lymphocytes and effect on phosphatases. J Enzyme Inhib Med Chem 20: 449-454, 2005.

17. Pinkney M, Kapur V, Smith J, Weller U, Palmer M, Glanville M, Messner M, Musser JM, Bhakdi S and Kehoe MA: Different forms of streptolysin O produced by Streptococcus pyogenes and by Escherichia coli expressing recombinant toxin: cleavage by streptococcal cysteine protease. Infect Immun 63: 2776-2779, 1995.

18. Walev I, Palmer M, Valeva A, Weller U and Bhakdi S: Binding, oligomerization, and pore formation by streptolysin $\mathrm{O}$ in erythrocytes and fibroblast membranes: detection of nonlytic polymers. Infect Immun 63: 1188-1194, 1995.

19. Zitzer A, Walev I, Palmer M and Bhakdi S: Characterization of Vibrio cholerae El Tor cytolysin as an oligomerizing poreforming toxin. Med Microbiol Immunol 184: 37-44, 1995.

20. Fadeel B and Orrenius S: Apoptosis: a basic biological phenomenon with wide-ranging implications in human disease. J Intern Med 258: 479-517, 2005.

21. Kaufmann SH and Earnshaw WC: Induction of apoptosis by cancer chemotherapy. Exp Cell Res 256: 42-49, 2000.

22. Reed JC: Double identity for proteins of the Bcl-2 family. Nature 387: 773-776, 1997. 
23. Youle RJ and Strasser A: The BCL-2 protein family: opposing activities that mediate cell death. Nat Rev Mol Cell Biol 9: 47-59, 2008.

24. Cory S, Huang DC and Adams JM: The Bcl-2 family: roles in cell survival and oncogenesis. Oncogene 22: 8590-8607, 2003.

25. Dejean LM, Martinez-Caballero S, Guo L, Hughes C, Teijido O Ducret T, Ichas F, Korsmeyer SJ, Antonsson B, Jonas EA and Kinnally KW: Oligomeric Bax is a component of the putative cytochrome c release channel MAC, mitochondrial apoptosis induced channel. Mol Biol Cell 16: 2424-2432, 2005.

26. Cory S and Adams JM: The Bcl-2 apoptotic switch in cancer development and therapy. Oncogene 26: 1324-1337, 2007.
27. Danial NN and Korsmeyer SJ: Cell death: critical control points. Cell 116: 205-219, 2004.

28. Wei YB, Fan TJ and Yu MM: Inhibitor of apoptosis proteins and apoptosis. Acta Biochim Biophys Sin 40: 278-288, 2008.

29. Pinkoski MJ, Brunner T, Green DR and Lin T: Fas and Fas ligand in gut and liver. Am J Physiol Gastrointest Liver Physiol 278: G354-G366, 2000.

30. Garrido C, Galluzzi L, Brunet M, Puig PE, Didelot C and Kroemer G: Mechanisms of cytochrome c release from mitochondria. Cell Death Differ 13: 1423-1433, 2006. 